\title{
Continuity and Change in the Midst of Ecological and Livelihood Transformation in Tengger East Java
}

\author{
Manggala Ismanto ${ }^{1}$, Nindyo Budi Kumoro ${ }^{2}$, Hatib Abdul Kadir ${ }^{3}$, Irsyad Martias ${ }^{4}$ \\ \{manggala@ub.ac.id ${ }^{1}$ \} \\ Universitas Brawijaya, Indonesia ${ }^{1,2,3}$ \\ National Chengchi University, Taiwan ${ }^{4}$
}

\begin{abstract}
The uplanders of Tengger around the Bromo Mountains and Semeru in East Java reflect the image of a traditional and isolated peasant community. This research argues that uplanders like the Tengger people are open to the outside world, especially in the economic sector where they are highly responsive to agricultural commodities, following the movement of the existing market. Accordingly, this study wants to probe how the relationship between the livelihoods of the agrarian sector and tourism in Tengger has undergone. Our studies have shown that Tengger can diversify agricultural activities into a non-farming economy, in our case is the tourism. Moreover, population growth and landhungry monoculture farming also have contributed to ecological crisis problems. This research aims to contribute and provide a new understanding of the Tengger community in today's situation, as well as increase the socio-cultural study of highland communities in Indonesia.
\end{abstract}

Keywords: Ecological Transformation, Livelihood, Traditional Community, Tourism

\section{Introduction}

The Tengger people living around the upper slopes of the Bromo and Semeru Mountains of East Java are traditionally categorized as the 'uplanders' in the socio-anthropological perspective. Unlike the lowland communities, the uplanders have been subjected to traditional agrarian-rural groups embedded with backwardness and marginalized communities. The influential anthropologist, Scott [1], states that the notion of marginality of highland communities in the Southeast Asia regions is not a given thing. Instead, it was shaped by sociopolitical and economic contradictions that have played in the historical context of the upland regions. In the next phase, they became resistant, differentiating themselves from people in the lowlands, which were close to the state. For the Tenggerese people, the story of the resistance could be traced back to the fall of the Majapahit Empire and then colonial periods. Therefore, the socio-cultural configurations that have developed in Tengger reflect the sense of being isolated and different from the surrounding communities, starting from subsistence, dialect, social structure to religion [2][3].

This research suggests that the Tengger community has shown of being engaged to the outside world since, over the centuries, even more, in the sense of the global market economy, the Tenggerese people actively respond to this practice. Hefner [2] notes that the cash crop trade interaction between the Tenggerese people and the outside community was strengthened when the rollout of the plantation program in the 19th-century during government and intensified throughout the government's green revolution program in the 1980s. During those periods, 
Tengger farmers cultivated the commodity crops that were considered the most profitable in the (global) market network, such as corn, sweet potatoes, cloves, coffee, potatoes, and chilies; as well as vegetables (cabbage, carrots, leeks, potato onions), fruit (oranges and apples) [4].

Furthermore, our research examines how the current agricultural transformation of the Tengger people has been driven by two aspects. First, the implications of ecological damages and diminished land fertility due to the excessive use of agrochemicals such as pesticides, fungicides, and fertilizers force the change of the commercial agricultural system of Tengger farmers [5]. The growing population and limited land availability in the Tengger also contribute the deforestation and erosion, threatening the inhabitants as Hefner [2] says that 'the history of agriculture in the Tengger mountains is the open-ended ecological crisis. Second, the "boom" of the tourism on Mount Bromo and cultural attractions in the Tengger community, offering Tengger people an alternative economy off-farm sector. Nowadays, we can find dozens of $4 \times 4$ Sports Utility Vehicle (SUV) cars, locally known as Jip, and homestay business or hotels that can be enjoyed in Tosari and Ngadiwono [6]. From these two viewpoints, the livelihoods currently in the Tengger community have shown some significant changes. For instance, twofloor modern-style houses, motorbikes, and the newest cars have become a daily panorama in Tengger villages.

Drawing on the discussion above, the relationship between the agricultural economy and tourism in the Tengger community is interesting to revisit. A great deal of research has stated that farmers have stepped into tourism activities, becoming an alternative for livelihoods to survive, which is caused by environmental crises. This phenomenon is in line with off-farm practices that are intensely focused on earning income outside agriculture [7][8][9][10]. However, those studies overlook that society's cultural and rational resilience in dealing with environmental problems may affect their lives. Also, studies on traditional farming communities perpetually view farmers as passive agents and less expansive, which are unable to diversify their activities into other commercial non-agrarian sectors such as the tourism industry. From this point of view, our paper analyzes the relationship between the agricultural economy in Tengger and community participation in the Bromo-Semeru tourism activities.

\section{Research Method}

This research was conducted in Ngadiwono Village, Tosari District, Pasuruan. This location was chosen because this village has been developed as one of the Tourism Villages in the Bromo Tengger Semeru (BTS) area since 2013. The appearance of tourism in this area has led to configure the mode of the non-agrarian economy, such as the engagement of residents in providing homestay accommodation, as well as car rental services. On the other hand, the people of Ngadiwono Village have dealt with agricultural productions, both subsistence (corn) and cash crop (potatoes and vegetables) activities. Therefore, this village is more suitable for our research question since there is a symmetrical arrangement between the agricultural and tourism activities.

We employ participatory observation and in-depth interview methods. During the twoweek fieldwork, we approached several community representatives such as village heads, traditional healers, potato farmers, and residents who participate in tourism (homestay owners and jip owners). We also collected secondary data such as village monographs, online news, and journals related to the discussions of livelihoods, ecology, and tourism across the Tengger area. 


\section{Results and Discussion}

\subsection{Tracing Livelihood Trails in the Tengger Mountains}

The Ngadiwono Villagers economically rely on vegetable plantations. Initially, they farmed corn, onions, cabbage. Corn is one of the subsistence crops nurtured for diet needs. As decades went by, potatoes have become the most valuable cash crop for the community since the 1980s. At that time, there was the expansion of potato nurseries, which improved plant productivity. Potato production is 1:5 between seed and harvest and increases to 1:25, assuming 1 kilogram of seed can produce up to 25 kilograms of yield. Accordingly, farmers were attracted to cultivate potatoes. Subsequently, farmers also plant other vegetables such as cabbages, carrots, onions, and broccoli. Approximately every family manages to sell all products above, but some groups specialize in particular products - cabbage, including plants with easy care. Like a potato, the cabbage is low-cost in the nurturing process, but the market value is low.

Tengger potatoes have become a leading commodity. This commodity has been shipped to several major islands such as Kalimantan, Bali, and Papua. Although Sulawesi and Sumatra already have their own local potato commodities, the Tenggerese people are confident that their potato's quality is the best and can beat other competitors. "If Bromo potatoes get harvested, the middlemen will neglect to buy up other potatoes from other places". Even more, they choose to wait for our potatoes. "If you can get Bromo potatoes, the other potatoes will not be worthy of selling", said our informant. Mostly Tenggerese farmers nurture Granola Kembang potato type, which can only be planted at a certain height. Several new varieties with better quality have been started to be planted, such as Granola L and Granola Nadia. Granola Nadia is good at its shape and short-term crops. In contrast, the Granola Kembang variety has an advantage in the production number, but its roundness (shape) is not good as the Granola Nadia.

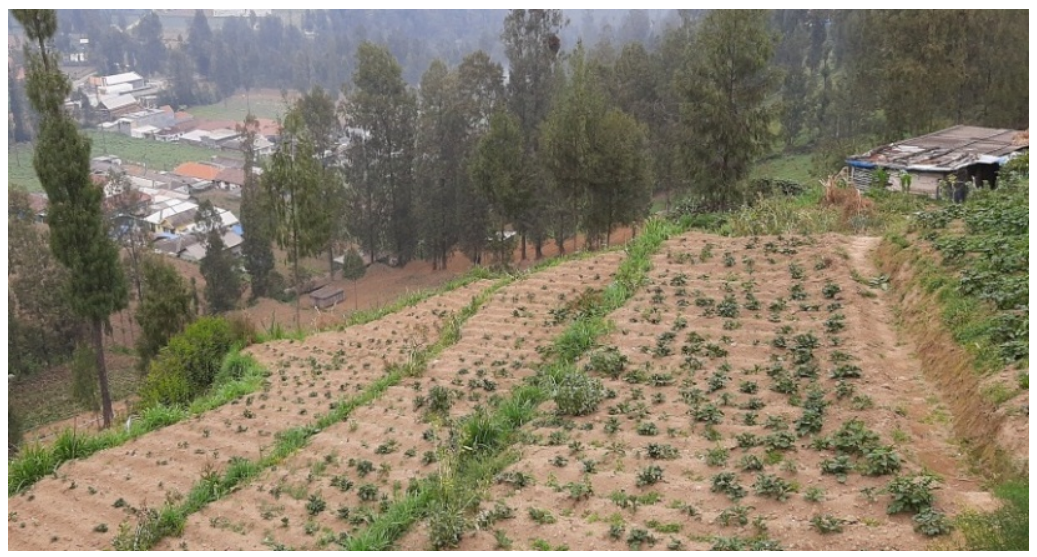

Picture 1. Potato Field in Ngadiwono Tengger (Source: Researcher documentation)

The Ngadiwono communities mostly manage their farm to grow potatoes - approximately the number of landholdings from 0.2 up to 3 hectares. Normally, one family owns three land parcels or 0.5 hectares that can be ideally cultivated for two quintals of potato seedlings. Within 3-4 months, a householder who manages 0.5 hectares of land can get 3-6 tons of potatoes. We note that the current potato market price can reach Rp. 8,000-9,000. As a result, the average 
monthly income of potato farmers can earn at least Rp. 2,000,000-3,000,000. When harvesting, farmers also sort out selected potatoes used as seeds that can be planted for the next season. By doing this strategy, reserving their own seeds, farmers are not necessarily buying seeds from other parties. Another strategy is cutting potato leaves shortly before harvest-time so that the growth of the potatoes prepared as for seeds will meet the standard. Medium size is preferable. Premium first-class seeds sold by the breeders may reach Rp. 37,000/kg, which is higher than the price of ordinary potatoes, which are only Rp. 8,000/kg.

Vegetable farming practice, especially potatoes, requires a large amount of water. Thus, farmers will wait for the rainy season to start the land preparation and later plant potato seeds. However, some farmers who have sufficient capital access can plant potatoes on their land throughout the year because they can access water for their land. They will look for springs in the Banyu Meneng hamlet area and install pipes to flow down water to the farm. The water price from that source is quite large, and it depends on the location. "Water from Banyu Meneng costs us around Rp. 10,000,000, because my farm is situated near provincial road and it is quite far from the water source", explained one farmer. There are even investors who pay Rp. 200,000,000.00 to install piped water from Banyu Meneng.

The farmers are also familiar with the profit-sharing mechanism between the landowners and tenant farmers, known as Protelon and Paron. Protelon regulates 2/3 profit-sharing for landowners and $1 / 3$ for the tenants. Landowners receive a larger portion because they are the ones who will bear the costs of production, such as seeds, fertilizers, water. Then the farmers obligate to control the maintaining crops, starting from planting to harvesting. At harvest time, by assuming the sales revenue reaches Rp. 15,000,000, the landowner will earn a profit portion of Rp. 10,000,000, whereas the cultivator will only get Rp. 5,000,000.

Furthermore, there is also a profit-sharing called Paron, where profits are equally divided. Practically, both the landowners and the tenants contribute to the process of productions. For example, the landowners will supply the seeds and water, while the worker will carry the fertilizer purchasing cost. By estimating Rp. 10,000,000 as of the total sale, each party will receive Rp. 5,000,000 for their profit. With this practice, some farmers interestingly said that there is a possibility that tenant farmers can gain higher profit than investors because the more they invest their labors in many lands, the more profit they can extract. For example, "if one farmer works in 10 farms, he will get Rp. 35,000,000 in one harvest period".

Apart from profit-sharing matters, farmers are also trapped in the landowner's debt system. Landowners will usually loan debt to farmers to farmers' means of productions, such as seeds, fertilizers, and maintenance costs. After harvesting, the indebted farmer will sell the potato to the middlemen traders. By these traders, the potatoes will be brought to regional markets in Batu, East Java. This place is the center for the regional potato trade, although the largest potato producer is in the Pasuruan area (Bromo Tengger area). From Batu, the potato will then be distributed to potential domestic markets, such as Jakarta, Magetan, Semarang, Surabaya, Malang, and Banyuwangi (Java Island), and to several markets in Papua, Bali, and Kalimantan. There are three well-known bosses (landlords) in this village, Pak Makmur, Pak Tera, and Pak Tentrem. These landlords control the potato economy in Ngadiwono since they have access to capital, such as finance, seeds, land, labor, and trade networks. Besides, they also expand their business to other units. Two of the three bosses, namely Pak Makmur and Pak Tera, also have 2-3 Jip Hardtop to open a tourism sector.

The prosperity that came from commodity crops in potatoes and other vegetables made people's lives economically improved. This improvement is demonstrated by the benefits obtained by both landowners and sharecroppers. Moreover, some brokers have an opportunity to accumulate their capital and diversify into tourism by developing Jip tour and homestay 
services. On the other hand, the potato commodity expansion also issues inherent ecological damage because the farming activity occupies steeply marginal lands that are prone to landslides' risks.

\subsection{Living in the Middle of an Ecological Transformation}

In the Tengger region, due to the rapid population growth, agricultural and ecological resilience becomes poor. In terms of fertility, dry land excessively exploited will lose its nutrients, then easily experience erosion and cause silting [5]. From population data compiled by Hefner [2], the Tengger Mountains show a significant population increase. In 1927-1980 in the Upper Slopes areas such as Tosari, Wonokitri, Podokoyo, Ngadiwono, and Mojorejo, experienced a significant increase in population, from 9,352 to 14,751 . This condition has an impact on increasing population density per $/ \mathrm{km}^{2}$ and affects land use. In Ngadiwono Village, there was an increase in population in the 2016 period, which reached 2765 with a population density of $250 / \mathrm{km}^{2}$. This population density is listed fourth in Tosari District villages, after Tosari, Kandangan, and Mororejo [11]. In terms of land use, it can be seen from the total land area in the Ngadiwono Village and the comparison of agricultural land use. From an area of 110,600 hectares, more than half of the entire land, 539.92 hectares, has been used as an upland agricultural area [11]. This data shows that the land use for agriculture is excessive for people's lives.

In Ngadiwono village, landslides are a problem faced by the community. A landslide occurred in mid-June 2020 on a cliff with a height of 70 meters. This landslide occurred on an elevation with a 60-degree slope with loose soil characteristics. Last year, roads in the village were disturbed due to landslides in the Ketuwon Hamlet area. For almost twelve days, the main road from Ngadiwono Village to Ketuwon Hamlet was covered with landslide materials. According to the information by the village head, the landslide land belonged to Perhutani. The vulnerability of the location on the slopes of Bromo, the Head of Tosari sub-district reminds "local people and tourists always to be aware of the danger of the rainy season because the Tosari region has a geographical location of mountains and slopes, potentially causing landslide threats" [12].

The Ngadiwono community has developed a coping mechanism to reduce the risk of landslides on plantation land by planting pine trees surround their land in the mountains. "When opening their land, people also plant these trees, and this is our rule, if you cut one tree, you must plant five trees", explained Dukun (Shaman) in Ngadiwono Village. Planting cypress trees provide several benefits to the community, both economically and ecologically. Initially, planting the trees for marking the territory or boundaries of someone's land. Besides, because people still use firewood for various household needs, pine trees are used as firewood sources. Ecologically, pine trees around the ground also help prevent landslides because of solid roots.

The condition of the Bromo slope ecosystem related to water resources also causes big problems for the community. Pasuruan Regency has a concern about a drought that occurs in the highlands around Bromo. Almost every year during the dry season, several villages around Bromo experience a clean water crisis. There are 23 villages in Pasuruan Regency that experience clean water difficulties every year. Over the years, through the Regional Disaster Management Agency (BPBD), the government has provided clean water distribution assistance with a budget of up to 1.1 billion [12]. In the long term, in early 2018, the government created a clean water supply program to solve this problem. This program is carried out by building a water pipe network in the Lumbang and Winagon Subdistricts, two districts experiencing the 
most severe water crisis. This program will be carried out in stages to distribute water to residents' homes through household pipe networks [13].

The problem of the ecological crisis in the form of the limited availability of clean water in the Tengger highlands can be traced through the historical traces of Ngadiwono Village's origins. According to elderlies' explanation, initially, the people in Ngadiwono Village lived in Wonojati. Wonojati is a settlement where residents always experience water shortages because they do not have a spring. Mbah Tanggul, a figure in Wonojati, discovered a spring with a large water reserve in the form of an "umbulan" because it follows his buffalo, which always returns to the cage bathed in mud. Mbah Tanggul told Wonojati residents about a better life near a spring. Residents are also interested in moving to spring by clearing land, and the village is now known as Ngadiwono, "a beautiful forest". The location where the springs were found is currently known as the "Ndase Banyu" spring.

The spring, which is currently referred to as "Ndase Banyu" is one of the residents' springs. The spring is considered sacred to the community because it is guarded by the spirit of the ancestors who opened the first village known as Mbah Tanggul, one of the three Danyang who protects the existence of Ngadiwono Village. In Ngadiwono Village's lives, it is believed that three Danyang are waiting for the village, namely Danyang Kahuripan, Danyang Banyu, and Danyang Pesetran. a commendation ceremony is always held by giving prayers and giving to Mbah Tanggul to thanks for the grateful for the spring's existence and its benefits for the village community. Apart from ritual events, this place is also guarded by unwritten rules. The rules that were agreed upon were that the residents were not allowed to cut down the tree stands surrounding the source and transfer land as agriculture around the spring. Maintaining the ecosystem around the spring is expected to maintain the quality and quantity of clean water. If there are residents who violate these rules, there will be supernatural punishment. A story was when a resident was forced to take firewood in a forest springs area for his celebration in the '80s. After the festival or ceremony is carried out, almost all the village children suffer from illness with no known cause. After the incident, none of the residents dared to take wood in the spring area.

In Ngadiwono Village, water is also a challenge that must be faced by the community because spring water is considered unable to meet the needs of the community whose population is always increasing. Although it is assumed that the spring has a reasonably large water discharge, the Ngadiwono Village Government considers that a program is needed to ensure that everyone can access water evenly. Also, population growth is a consideration for the village to find alternative springs beside the main Ndase Banyu spring. A program was executed during the corona pandemic in mid-2020 to distribute water to every resident's house. "We brought water from a spring, it happened to be located below, so we bought it to buy a vacuum cleaner. We drag it to the village from the existing source, only to reach the lower part of the village from there we pull it up. The source is in the east of Mororejo Village", explained the Village Head. The water source near Mojorejo is combined with Sumber Air Ndase Banyu to meet the needs of clean water in Ngadiwono Village.

From the environmental transformation problem that occurred in Ngadiwono Village, we can see how the community's adaptation pattern is to avoid an ecological crisis. Regarding the threat of landslides in vegetable and potato fields, residents are indirectly using mountain pine trees whose roots are useful for holding the soil. A water crisis's potential is faced with the community's tradition of protecting springs through customary rules and supernatural sanctions. The village government carries out efforts to preserve water access from the threat of increasing population in the village by increasing the discharge of springs and channeling it directly to residents' homes. Besides, there are differences in water use for domestic purposes and potato 
plantations based on the source of water used. In this way, the people of Ngadiwono demonstrate that there is a resilience and adaptation capacity to mitigate ecological problems associated with landslides and the clean water crisis.

\subsection{Tengger Tourism: Diversification of the Potato Economy}

The tourism phenomenon around Bromo Tengger and Semeru has appeared for centuries, and during that time the Ngadiwono people were rarely involved in it. Mount Bromo (Iyang plateau) or Ranupani Semeru has been visited by travelers since the 18th century, especially when the Dutch East Indies government opened enclaves of East Java plantations. Many travelers, naturalists, and European families visited the East Java area due to its beautiful landscape and to control their plantations. Many buildings were built in remote areas of East Java to accommodate hunting activities and plantation visits by westerners [14]. Cribb [15] noted that since the early 20th century the Bromo Tengger Semeru area had been regularly visited by Europeans in the Dutch East Indies. The colonial government prompted establishing the country's official tourism bureau (Officiele Vereeniging voor Touristenverkeer) in 1908 to promote international tourism. The bureau's tourist route was the Javanese tourist safari, from West Java and ending in East Java to visit Tosari, enjoy the sunset on Mount Bromo, before finally ending in Surabaya.

After independence, tourism in Tengger was more developed starting in the 1970s, especially in Mount Bromo's destination. Road construction, public transportation, and location close to the main Java land routes make it easier for tourists to access. Bromo tourism provides tourists with experiences that are not much different from what we see today, such as watching the sunrise, riding a horse across the Sand Sea, and climbing to the top of the Bromo crater to wait for the sunrise. Some people also visited Mount Penanjakan, another viewpoint on the edge of the crater. However, the Tenggerese began to be involved in the tourism market, even only in a few villages outside Ngadiwono. Most tourist accommodation provision is concentrated in the village of Cemoro Lawang on the edge of the Caldera rim, with additional facilities in villages at varying distances such as Ngadisari, Wonotoro, Wonokitri, and Tosari [16].

Entering the 2000s until today, TNBTS is one of East Java and Indonesia's main tourist destinations. Among Tenggerese villages, Cemoro Lawang and Ranupani are still the leading tourist destinations. Some people in these villages are involved in the tourism business by renting horses, jips, lodging, and offering tour guides to Mount Semeru. Some other operate restaurants and gift shops. In a survey of several Tengger villages (Cemoro Lawang, Ranupani, and Ngadas), Hakim and Nakagoshi [17] indicated that $85 \%$ of the respondents responded positively to this tourism industry.

This positive response could be accurate if we look at the blatant prosperity in the villages above. As an indication of the importance of tourism to the local economy, Cochrane [18] shows that rural communities in Tengger earn the same or more from tourism than from agriculture (especially villages that are intensively involved in tourism Tosari, Ngadas, Ngadisari, or Ranupani). The tourism industry in Bromo, both international and domestic, has increased in the last decade, driven by the spreading of popular films and novels that tell stories against this landscape's background. Since the last few years, popular events such as the Bromo Jazz music concert and the Bromo Marathon festival have emerged.

Ngadiwono Village was also affected by the rapid development of tourism in Bromo after the 2000s. Villagers are getting used to seeing tourists passing by in the village. Even this village is not on the main Bromo route (4 kilometers from Tosari, the village center of Bromo tourism activities in the Pasuruan area). 
This involvement was driven by the need for facilities and accommodation for Bromo tourists which are increasingly unable to be met than previously available, especially tourist delivery services and lodging. Batoro, one of the youth leaders and tourism actors at Ngadiwono said that the participation of the Tenggerese people in tourism began intensively through transportation services using a "Hardtop" Jip (Toyota Land Cruiser FJ40) in 2009. Before that, tourists will use travel agents from cities (Malang and Surabaya) who deliver them directly to the Mount Bromo area.

Since 2009 Batoro and several youth friends in other villages have founded "Paguyuban Tengger Brang Kulon" as an organization that manages transportation services for Bromo tourists exclusively. They limit travel agents from "bawah" (lowlanders) and also impose strict rules for outsiders who are involved in Bromo tourism. According to Batoro, the goal is for the Tenggerese to enjoy Bromo tourism's benefits and not be controlled by outsiders. The district government and various stakeholders in Pasuruan have also strengthened the association regulations, which were later promulgated into regional regulations.

Initially, this Hardtop Jips owner's organization was still under one hundred people. Then it grew to about three hundred members from three villages in Tosari sub-district. In Ngadiwono, there are now thirty-five Hardtop's owners. Some members own two to three Jips, with the price of this car ranging from fifty to one hundred million rupiah. This transportation service benefits are quite large, especially during the peak seasons (Idul Fitri, Christmas and New Year eve, or Kasodo Ceremony). The price for one route is six hundred thousand rupiahs back and forth from the post in each village to Bromo Peak.

In addition to Hardtop transportation services, the Ngadiwono people's involvement in tourism is also in providing lodging or homestay services. In Ngadiwono, there are currently eight homestays which are always full of Bromo tourists during the holiday season. This homestay business emerged in 2009 and 2010, responding to the high number of tourists coming to Bromo. The only hotel in the Bromo area, Bromo Cottage, cannot always accommodate all the tourists who come, apart from its high rates. At that time the Village Government took the initiative to reactivate the Tourism Awareness Group (Pokdarwis) to welcome this opportunity. The strategy is to ask villagers who have many bedrooms in their homes to use them as lodging. Pokdarwis then collaborated with other travel agents in Bromo to promote these homestays in Ngadiwono. One of the homestay owners in Ngadiwono is Bu Inas. She has two houses in Ngadiwono, one of which is rented out as a homestay. Bu Inas and other homestay owners then received training at the Pasuruan Tourism Office to provide hospitality and exemplary service to the guests in this business.

To improve the nuance of a tourist village, villagers are also trying to beautify this village's face. They renovated the village's front gate and decorated a colorful garden with the words "Ngadiwono Village". Since the 2010s, tourism life in Ngadiwono has been going on massively. Every weekend, the average homestay is always fully rented by tourists from both big cities in Indonesia and foreign tourists. As during Bromo Marathon, an international running competition has been held since 2013, all homestays in Tosari sub-district have all been rented by the event participants. Even Some of the residents' houses were also rented at the time of the event.

The average homestay rental in Ngadiwono costs 250 thousand rupiahs per room. The homestay owner does not provide guests food services, but provides all the utensils and necessities for cooking. According to Bu Inas, most of her homestay guests come from Bandung, Jakarta, and Surabaya. Tourists in Ngadiwono will usually rent a Jip in this village to be delivered to Bromo, so that the lodging business and Jip transportation services there are integrated. 
However, not all Ngadiwono people are able to participate well in this tourism business. If we relate to the previous potato farming activities, both Jip and homestay owners in Ngadiwono were mostly wealthy potato farmers. Batoro, who now controls the tourist transportation business in Ngadiwono, is a successful potato farming family. Besides owning a potato field of more than three hectares, the Batoro family is also the only supplier of potato seeds for Ngadiwono farmers (apart from the government). He provides many funds for farmers who are short of money or land to farm with the 'three-share system' (telon) as described above. With the potato farming business's success, it was not difficult for his family to provide three hardtop units worth hundreds of millions of rupiah to be used in Bromo tours. Apart from the Batoro family, the hardtop owners in Ngadiwono are dominated by potato middlemen who are patrons for farmers in Ngadiwono. There are three other landlords who each have more than one hardtop unit. Like in the agricultural business, the Jip owner does not have to drive himself to transport tourists. They use labor from their neighbors and youths from other villages to run their hardtop with a profit-sharing system.

The same pattern also occurs in the homestay business. Almost all homestay owners in Ngadiwono are middlemen or potato landlords with more than three hectares of land. Bu Hajjah Ilyas, apart from a wealthy skipper and farmer, has also built a three-floors homestay worth almost one billion rupiah. Although not a middleman, Bu Inas comes from the village head's family who owns a land area of more than five hectares. The house that turned into his homestay was built for 500 million in 2015, resulting from his profits as a potato farmer.

This pattern shows that tourism is neither an alternative nor a substitute for the agricultural economy, but instead as a way for Tengger farmers to diversify their profits from advanced potato farming. Although tourism provides additional benefits for the Ngadiwono people, almost all of them state that agriculture's economic sector remains the main one. As Bu Inas said, "If there is a chance to get other sustenance, why not? The profit from potato plantations for us is common. Tourism is just a supplement. Our main income still from farming. No one here has left the farm. Even though we go to Bromo by jip at night, we still go to the fields in the morning".

\section{Conclusion}

Research data that departs from literature studies show that Tenggerese are the most open to the outside world and responsive to global market dynamics. Start from the ever-changing market of commodity crop farming to international tourism. From this openness, we see two implications, changes, and continuity in aspects of Tengger culture. Significant changes are the problems of the population's economy and the ecology of Tengger. The change of commodity crops (cash crop) from maize, potato to fruit is currently causing land privatization and land scarcity for small farmers and lower-class communities. This condition encourages diversification of livelihoods to non-agricultural areas (non-farming) such as entrepreneurship and into the tourism sector, although capital control and the poor-rich structure are maintained. Other changes include environmental damage due to population growth and land-hungry monoculture farming for the above commodities. Agriculture carried out in critical lands such as on the slopes of a hill has caused landslides to occur frequently in the Tosari area, which threatens its inhabitants' safety, and there is a clean water crisis.

Tourism in Bromo Tengger Semeru National Park, which has been around for a long time, is now getting more robust and becoming a new opportunity for the Tengger people's livelihoods. Once they can overcome the problem of degraded land and continue to benefit from 
potato farming, tourism becomes a way for the successful people in Tengger to diversify their profits from potato farming. This fact shows that the socio-economic structure has not changed too much (wealthy farmers become the controlling capital owners of the tourism business).

\section{References}

[1] J. C. Scott, The art of not being governed: an anarchist history of upland Southeast Asia. New Haven, Conn: Yale University Press, 2011.

[2] R. W. Hefner, A. Wisnuhardana, I. Ahmad, and I. Baehaqi, Geger Tengger: Perubahan sosial dan perkelahian politik. Lembaga Kajian Islam dan Sosial (LKIS), 1999.

[3] S. C. Headley, "Andrew Beatty, Varieties of Javanese Religion. An Anthropological Account. Cambridge, Cambridge University Press, 1999, xix +272 p., réf., index, gloss., ph., carte ('Cambridge Studies in Social and Cultural Anthropology' 111)," L'Homme. Rev. française d'anthropologie, no. 156, pp. 295-297, 2000.

[4] BPS Kabupaten Pasuruan, "Kabupaten Pasuruan dalam Angka 2019.," Badan Pusat Statistik Kabupaten Pasuruan, 2020. .

[5] Y. Yuliati, Perubahan ekologis dan strategi adaptasi masyarakat di wilayah Pegunungan Tengger. Universitas Brawijaya Press, 2011.

[6] L. Hakim, "Cultural Landscapes of the Tengger Highland, East Java," in Landscape Ecology in Asian Cultures, Springer, 2011, pp. 69-82.

[7] J. C. Scott, "The moral economy of the peasant: Subsistence and rebellion in Southeast Asia," Yale UP (New Haven), 1976.

[8] S. Cederroth, Survival and profit in rural Java: the case of an East Javanese village. Curzon Press, 1995.

[9] B. White, "Rice harvesting and social change in Java: An unfinished debate," Asia Pacific J. Anthropol., vol. 1, no. 1, pp. 79-102, 2000.

[10] L. Potter, "Agrarian transitions in Kalimantan: Characteristics, limitations and accommodations," Borneo Transform. Agric. Expans. Southeast Asian Front., pp. 152-202, 2011

[11] BPS Kabupaten Pasuruan, "Kabupaten Pasuruan dalam Angka 2019," Badan Pusat Statistik Kabupaten Pasuruan, 2012.

[12] M. Arifin, "5 Titik di Lereng Bromo Longsor, Warga dan Wisatawan Diimbau Waspada," Detik News, 2020. [Online]. Available: https://news.detik.com/berita-jawa-timur/d-4922630/5-titik-dilereng-bromo-longsor-warga-dan-wisatawan-diimbau-waspada.

[13] J. Arifin, "Setahun, Distribusi Air Bersih di Pasuruan Telan Rp 1,1 M," Radar Bromo, 2018. [Online]. Available: https://radarbromo.co.id/2018/12/26/setahun-distribusi-air-bersih-dipasuruan-telan-rp-11-m/.

[14] L. Hakim, "Planning for nature-based tourism in East Java: recent status of biodiversity, conservation, and its implication for sustainable tourism," ASEAN J. Hosp. Tour., vol. 7, no. 2, pp. $155-167,2008$.

[15] R. Cribb, "International tourism in Java, 1900-1930," South East Asia Res., vol. 3, no. 2, pp. 193 204, 1995.

[16] J. Cochrane, "Indonesian national parks: understanding leisure users," Ann. Tour. Res., vol. 33, no. 4, pp. 979-997, 2006.

[17] L. Hakim and N. Nakagoshi, "Kasodo, tourism, and local people perspectives for Tengger Highland Conservation," in Proceeding 11th Biennial Conference of International Association for the Study of Common Property IASCP, 2006, pp. 19-23.

[18] J. Cochrane, "Factors influencing ecotourism benefits to small, forest-reliant communities: A case study of Bromo-Tengger-Semeru National Park, East Java," in Ecotourism for forest conservation and community development: Proceedings of an international seminar, 1997, pp. 151-168. 